МРНТИ 06.52.17

JEL Classification: M1; M14; M54; J24

https://doi.org/10.52821/2789-4401-2021-4-64-81

\title{
CORPORATE SOCIAL RESPONSIBILITY AND ORGANIZATIONAL COMMITMENT: EVIDENCE FROM KAZAKHSTAN
}

\author{
M. Arslan', D. Abeuova ${ }^{1 *}$ \\ ${ }^{1}$ KIMEP University, Almaty, Republic of Kazakhstan
}

\begin{abstract}
Purpose: This study aims to analyze how Corporate Social Responsibility (CSR) affects employees' organizational commitment.

Design / methodology / approach: Data were collected through a self-administered survey questionnaire. A total of 230 complete questionnaires were obtained from restaurant employees in Kazakhstan. The Cronbach alpha, descriptive statistics, correlation analysis, and regression were employed to examine the association among corporate social responsibility and organizational commitment.

Findings: The findings reveal that employees show more commitment to organization if involved in CSR activities. Results reveal a significant positive relationship of all four perspectives of CSR with organizational commitment.

Practical and Theoretical Implications: This study sheds light on the reconsideration of CSR initiatives in developing loyal employees. This study also confirms the social identity theory and suggests that employees are social actors who join the organization if it best suits their self-interests, especially in context of CSR.

Originality / value: Notwithstanding the significance of CSR awareness, several studies have explored customers' and firms' perceptions, whereas only a few studies have explored employees' CSR perceptions. This study deepens the knowledge and aftermath of CSR from the employees' perception. It is pivotal to know the employees' perceptions of CSR activities for restaurant management because employees turn CSR statements into actions. According to our best knowledge, this is the first study that investigates the impact of CSR on the organizational commitment of service sector employees in Kazakhstan.

Keywords: corporate social responsibility, restaurants, organizational commitment, Kazakhstan, correlation, regression.
\end{abstract}

\section{INTRODUCTION}

Recently, corporate social responsibility (CSR) has been a hot topic and gained evolving interests from the board of directors, regulators, and research scholars around the globe. Several studies have focused on CSR in different industries such as logistics [1], tourism and hospitality industry [2-5] among others. Mozes, Josman [1] recognized the inevitability of harmonizing effectiveness and improving a constructive image through social and environmental responsibility. Musgrave [2] found that more than $50 \%$ of surveyed industry professionals argued the awareness and pressures from customers to involve in CSR activities. Therefore, firms are under severe pressure from auditors, regulators, and customers to seek advice and guidance about CSR activities [3]. Tsai, Tsang [4] documented that "in the context of the hospitality and tourism industry, the concerns on CSR are a response to the guidelines established by the World Travel and Tourism Council and the United Nation World Tourism Organization (UNWTO), as well as the environmental awareness raised by the Green Hotels Association" [4, p.1143]. Marin, Ruiz [5] argued that CSR is used as a marketing tool by many firms which helps increase customer satisfaction and image of the firm. Similarly, scholar also found that potential employees also consider and give weightage to CSR activities while finding jobs [6]. Despite its importance, this studies are limited to explore the effect of CSR and employee [7], and this area is still progressing. Several reports highlighted the importance and benefits of CSR activities in potential skilled 
employees [8]. Literature suggests that those manufacturing companies may have more pressure for CSR initiatives from media and society that are involved in the discharge of detrimental waste into the environment $[9 ; 10]$. On the other side, nonmanufacturing firms may face less pressure have less pressure because they have less hazards compared to their counterparts $[11 ; 12]$. In sum, CSR is essential for all the stakeholders inside and outside of the firm. Scholars also contended that firms involve in CSR activities to tackle the pressure of media and society as a whole to promote their good image [13]. Such firms ponder employees as internal customers, and the success of the firm relies on their commitment. Scholars argued that CSR is the application of international standards in doing business [14]. Yerniyazova and Smailova [14] argued that CSR is taken as a phenomenon and firms consider CSR as preserving existing ones and creating new jobs, paying taxes in full, and appropriate employee compensation package. Scholars argued that the Republic of Kazakhstan (RK) is perhaps the leader in the field of CSR among all Central Asia. CSR can be tracked back in mid 1990s in independent Kazakhstan with the entry of foreign companies to the market, which had already demonstrated their social responsibility [14]. However, the CSR concept is still considered relatively new in Kazakhstan and the awareness of CSR is evolving [15]. Yet, a shared understanding of the concept of CSR in Kazakhstan has not yet been formed. Though scholars underlined to investigate the link among organizational commitment and CSR $[16 ; 17]$ however, CSR in Asia, especially in Central Asia is still under research and unclear [15; 1820]. In addition, employees' self-evaluation of CSR initiatives is either absent or neglected. This provides us an opportunity to conduct this study and ponder the CSR from employees' perspectives. The question arises that how employees' perception of CSR affects organizational commitment?

Drawing on a sample of 230 employees of restaurants in Kazakhstan, this study investigates the employees' perception of CSR and its effect on organizational commitment (OC). Nevertheless, the studies on CSR are growing, this area is still limited especially in the service sector of an emerging economy like Kazakhstan.

Literature Review. Donaldson and Preston [21] contended CSR as a method of self-regulating mechanism. Chapple and Moon [22] emphasized the recognition and significance of CSR worldwide. Nevertheless, the conceptualization of CSR is still different, and scholars have not reached to a collective opinion on CSR [23] due to distinctions in socio-economic factors among different research contexts. Several firms voluntarily publish CSR reports to signal their commitment to act socially responsibly [24; 25], gain business legitimacy [26], protect firm value and reputation [27], reduce information asymmetry between firms and investors [28; 29], and signal future financial performance [30] due to evolving significance of CSR activities for firms' future financial performance. Therefore, this divergence reflects different perspectives of CSR and substantially affects the development and implementation of CSR policies and initiatives. Culture is a shared deposit of knowledge, experience, and behavior which aids in the classification of one society from other [31]; therefore, it is significant to comprehend the impact of cultural factors on CSR. Indubitably, cultural expectations motivate corporate social responsibility initiatives and developmental differences and impediments among developed and developing countries. The studies on CSR are developing to compare and contrast the distinctions in CSR among different contexts and countries, however, most of the studies have primarily focused on Western European and North American countries [32; 33]. Most of the existing CSR studies have evolved in Western countries and there is a dire need to conduct similar studies in developing countries, especially in Asia, due to recent business developments. In addition, the challenges and peculiarities are different in Asia as compared to their Western counterparts, which may challenge the uniformity of policies. Scholars argued that employees' attitudes are influenced by societal norms and found lower CSR levels in Asia than Western counterparts [20; 34]. Scholars also found diverse responses among European, North American, and Asia countries [35].

Chapple and Moon [22] documented that CSR research is limited in Asia and is not widely explored. On the other side, western researchers and practitioners have highlighted the importance of CSR and increase its awareness. Asian countries usually draw their policies on western practices and ideas. Therefore, they have focused more on environmental issues in recent years. Forsyth [36] emphasized the need of public-private cooperation in promoting the technology transfer among Philippines and Thailand while Hills and Welford [37] examined the governance characteristics of environmental responsibility among Chinese firms. The studies are still limited to some specific Asian industries, and there is a need to conduct more research. Ali, Nasruddin [38] examined the association among internal CSR and OC in the banking sector and found a significant positive 
relationship. Roudaki and Arslan [39] also found similar findings in the service sector of Pakistan. Turker [40] conducted a study to investigate the relationship among CSR and OC of the employees on the lenses of Social Identity Theory (SIT). SIT contends that individuals have affiliations with related group and identify and define themselves accordingly. As a result, their CSR perception provides positive commitments and outcomes $[41 ; 42]$. Turker [40] found that CSR to social and non-social stakeholders, employees, and customers were the significant predictors of organizational commitment. He did not find any link of CSR to employee commitment and government. Brammer, Millington [43] conducted a study to investigate the relationship of three aspects of socially responsible behavior (CSB) on organizational commitment (OC) among employees of a financial service company. Drawing on a sample of 4712 employees, they found that external CSB has a positive association with $\mathrm{OC}$ and that the contribution of CSB to OC is at least as significant as job satisfaction.

It is evident from the existing literature that employees show more loyalty and commitment towards ethical and socially responsible organizations, and they feel satisfied and distinct. Additionally, Gong, Chang [44] contended that ethical and social responsibility promotes exchange of relationships among employees and consequently their commitments towards the organization. Farooq, Payaud [45] found that CSR toward employees is the strongest predictor of employees' trust, identification, and affective organizational commitment out of four CSR components. Du, Bhattacharya [46] reported that psychological contract theory and Internal marketing theory may help in technology transfers. In Asia, only a limited number of studies have been conducted which focuses only on few industries. Mory, Wirtz [47] conducted a study among employees of a renewable energy company and found that internally perceived CSR strongly impacts employees' affective organizational commitment and comparatively low influences normative organizational commitment. They also documented that affective commitment mediates normative organizational commitment. Mensah, Agyapong [48] conducted a study in Ghana and documented a strong positive association between engagement in CSR and employee commitment. They also documented that this relationship becomes insignificant by controlling years of working and educational level. However, Gender does not confound this relationship. Similarly Thang and Fassin [49] conducted a study in Vietnam and found that internal CSR has a significant positive association with OC. They argued that training and education, health and safety, and labor relations had a significant impact on organizational commitment, however social dialogue and work-life balance has no significant association with organizational commitment. Kim, Woo [6] conducted a study to investigate the effect of CSR on quality of working life, job satisfaction, and overall quality of life. They found that philanthropic and economic CSR positively affected quality of working life, while legal and ethical CSR did not affect it. Similarly, Khaskheli, Jiang [50] conducted a study to investigate the relationship between CSR and organizational citizenship behavior. They found a positive and significant association of employees' CSR perception with organizational citizenship behavior, affective commitment, and intrinsic job satisfaction.

Organizational commitment is an extensively studied concept in organization psychology [51] and denotes the affiliation of employees with their firms [52]. Scholars argued that committed employees have trust in the organization's mission and vision which provides them motivation to make positive contribution in achieving them [53]. Scholars divided the organizational commitment model into three different dimensions; continuance commitment (perceive high costs), affective commitment (positive attachment), and normative commitment (moral obligations) [53-55]. A meta-analysis of these three parts of organizational commitment was performed by Meyer, Stanley [55]. They reported a significant positive relationship with organizational citizenship behavior, stress, attendance, and performance. Several scholars have only considered affective commitment to study OC $[40 ; 56]$. Based on a similar perspective, this study also only used affective commitment to investigate its link with perceived CSR. This study is similar to the study of Roudaki and Arslan [39]. Linfei and Qingliang [57] reported CSR as capital rather a cost in their Chinese study. They found that CSR engaged firms performed better both economically and socially as compared to their counterparts. Ali, Nasruddin [38] conducted a study in the Jordanian banking sector and investigated the link between internal CSR and OC. They found a positive relationship among internal corporate social responsibility and OC. On the other side, Murphy and Abeysekera [58] found that Indian software firms adapted dual strategies in reporting CSR activities. Scholars found that employees incline more recognition and value towards socially responsible organizations and show significant commitment to such organizations [39; 49]. Similarly, Gong, Chang [44] 
also contended that ethical and social responsibility increases employee commitment towards the organization due to the positive image of such organizations in society. Mostly loyalty and commitment are considered as one topic, however, scholars argued them as two separate topics. In organizational behavior literature, several scholars have defined organizational commitment differently. Some scholars have defined organizational commitment as an attitudinal phenomenon [53] while others defined it as a behavioral phenomenon [59] which involves moral obligation. Commitment enhances the moral obligation and more committed employees find ways to increase efficiency. On the other side, customers' attachment is called loyalty and does not involve any obligation. It is found that committed employees exercise autonomy and self-control without requiring extra supervision and willing to do any duty. Scholars argued that loyalty is driven by commitment and it is more stressful [60] where employee performs duty beyond the job's requirements. In recent years, universities have incorporated CSR in their curriculum due to societal demand and are adapting more sustainable solutions [60]. The CSR measures are still under debate, and several scholars have used different CSR measures [39; 40]. This study adapts the CSR frame of Carroll [61] for its suitability for the last 40 years. Roudaki and Arslan [39] also used a similar framework in their CSR research. We adopted the quantitative approach due to nature and objectives of the of the study. Carroll [61] divided CSR into four dimensions of economic, legal, ethical, and philanthropic. This study takes these all four dimension as independent variables, while organizational commitment was taken as a dependent variable. This study developed and proposed a theoretical model for exploring the link among CSR and organizational commitment, as presented in Figure 1.

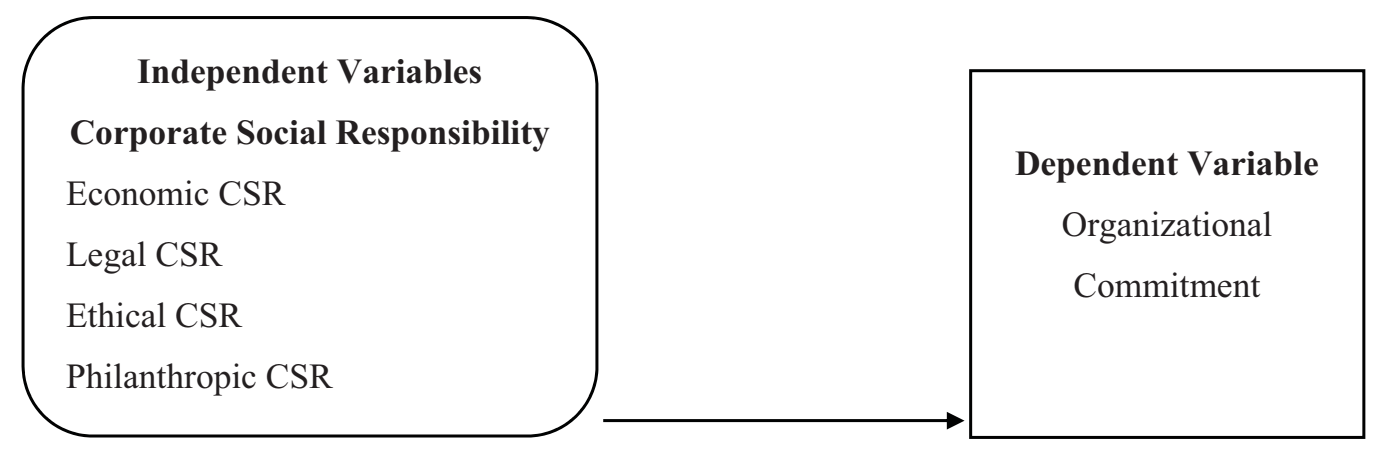

Figure 1 - Theoretical Model

Note - developed by authors.

Methodology. This section expounds on the methodology of the study. This study developed a questionnaire and took organizational commitment as dependent variable while four dimensions of CSR (such as economic, legal, ethical, and philanthropic) as independent variables (Figure 1). We adapted the CSR scale from Lee, Lee [62] due to broader acceptability and use in existing literature [39]. The scale was comprised of 29 items, measuring the four dimensions of CSR i.e., economic, legal, ethical, and philanthropic. Philanthropic CSR has 8 items while economic, legal, and ethical CSR have 7 items each, and all 29 items were measured on the fivepoint Likert scale from "strongly disagree to strongly agree". OC scale was adapted from Allen and Meyer [53] and has 8 items. These items were also measured on five-point Likert scale. A pilot study was also conducted to test the reliability of the scales. The questionnaire was sent to ten respondents to check the reliability of the scales. The questionnaire is available as Appendix A.

Sample and Data analysis. The data were collected from service sector employees in Kazakhstan by a self-administered survey method. The questionnaire was translated to Russian and Kazakh languages because majority of people understand both languages. In total, 20 big restaurants were selected from the Almaty region of Kazakhstan through purposive sampling. Only those restaurants were selected that have more than 15 employees. After selecting the restaurants, we sent 15 questionnaires to each restaurant, thus, a total of 300 questionnaires were distributed. This also helps in assigning equal weights. After following up, we received 250 filled questionnaires, 20 questionnaires were excluded from the final sample due to incomplete or wrong fillings. Thus, this provided us a final sample of 230 . 
Overall, the response rate was $76.6 \%$ that is acceptable because Welford [35], and Roudaki and Arslan [39] also found a comparative percentage in the other Asian countries. We analyzed the data with the help of SPSS 24. We took gender as control variable and performed the descriptive statistics, correlation, and regression analysis. Table 1 reveals the results of Cronbach's alpha ranged from 0.781 to 0.920 which shows the acceptability and reliability of the scales.

Table 1 - Results of Cronbach's Alpha

\begin{tabular}{|c|c|c|c|}
\hline Sr\# & Variables & Items & Cronbach's Alpha \\
\hline 1 & Economic CSR & 7 & 0.920 \\
\hline 2 & Legal CSR & 7 & 0.878 \\
\hline 3 & Ethical CSR & 7 & 0.812 \\
\hline 4 & Philanthropic CSR & 8 & 0.843 \\
\hline 5 & Organizational Commitment & 8 & 0.781 \\
\hline Note - compiled by the authors
\end{tabular}

Results. Table 2 reveals the results of demographic variables. The sample consisted of employees of restaurants in Kazakhstan. It can be seen that the service sector, especially restaurants, are dominated by females, who represent $52.17 \%$ of the total sample size. The male respondents were only $47.83 \%$. Majority of the respondents ( $42.61 \%$ ) were aged between 25 to 31 years old, while of $26.09 \%$ respondents were 32 to 38 years old. There were also very young respondents who aged from 18 to 24 years and represented $21.74 \%$ of total population.

Findings also show that $35.65 \%$ of respondents have a graduate degree while $33.48 \%$ have a postgraduate degree. The $30.87 \%$ of respondents have an undergraduate degree. At the end, the findings reveal that most of the respondents $(48.70 \%$ ) have less than 6 years of experience. while only $18.70 \%$ of respondents have more than 15 years of experience.

Table 2 - Results of Demographic Variables

\begin{tabular}{|c|c|c|}
\hline Demographics & $\mathrm{N}$ & $\%$ \\
\hline \multicolumn{3}{|l|}{ Gender } \\
\hline Male & 110 & $47.83 \%$ \\
\hline Female & 120 & $52.17 \%$ \\
\hline \multicolumn{3}{|l|}{ Age } \\
\hline $18-24$ years & 50 & $21.74 \%$ \\
\hline $25-31$ years & 98 & $42.61 \%$ \\
\hline $32-38$ years & 60 & $26.09 \%$ \\
\hline 39 and above years & 22 & $9.57 \%$ \\
\hline \multicolumn{3}{|l|}{ Education } \\
\hline Undergraduate & 71 & $30.87 \%$ \\
\hline Graduate & 82 & $35.65 \%$ \\
\hline Postgraduate & 77 & $33.48 \%$ \\
\hline \multicolumn{3}{|l|}{ Experience } \\
\hline Less than 6 years & 112 & $48.70 \%$ \\
\hline 6-10 years & 45 & $19.57 \%$ \\
\hline $11-15$ years & 30 & $13.04 \%$ \\
\hline 16 and above years & 43 & $18.70 \%$ \\
\hline \multicolumn{3}{|l|}{$\mathrm{N}=230$} \\
\hline
\end{tabular}


Table 3 reveals the results of correlation analysis among independent and dependent variables while controlling the effect of gender. The results show that a positive relationship between all four dimensions of CSR and organizational commitment. Nevertheless, the OC has a moderate correlation of around 0.25 with CSR dimensions. This implies that as the level of awareness about dimensions of CSR increases, the employees show more commitment to the organizational objectives.

Table 3 - Results of Correlation Analysis

\begin{tabular}{|c|c|c|c|c|c|c|}
\hline & $\begin{array}{l}\text { Control } \\
\text { Variable }\end{array}$ & Economic CSR & $\begin{array}{l}\text { Legal } \\
\text { CSR }\end{array}$ & $\begin{array}{l}\text { Ethical } \\
\text { CSR }\end{array}$ & Philanthropic CSR & $\begin{array}{c}\text { Organizational } \\
\text { Commitment }\end{array}$ \\
\hline Economic CSR & \multirow{5}{*}{ Gender } & 1 & & & & \\
\hline Legal CSR & & 0.283 & 1 & & & \\
\hline Ethical CSR & & 0.107 & 0.241 & 1 & & \\
\hline Philanthropic CSR & & 0.246 & 0.347 & 0.394 & 1 & \\
\hline $\begin{array}{l}\text { Organizational } \\
\text { Commitment }\end{array}$ & & 0.250 & 0.276 & 0.246 & 0.287 & 1 \\
\hline
\end{tabular}

Table 4 shows the results of regression analysis for Model 1 and Model 2. Model 1 takes gender as control variables while Model 2 takes all four dimensions of CSR (i.e., economic CSR, legal CSR, ethical CSR, and philanthropic CSR) as independent variables and investigate their impact on a dependent variable (i.e., organizational commitment). Several existing studies also took gender as control variable and theoretical background on the relation between gender and organizational cynicism (OC) is very slim. Most of the studies that control for gender variable found no significant effect of gender on organizational cynicism [63; 64]. Model 1 also reveals an insignificant positive relationship between gender and organizational commitment. However, the $\mathrm{R}^{2}$ is $0.21 \%$ which can be ignored. The primary purpose of this regression was to control the effect of gender in Model 2.

Model 2 reveals the results of all four dimensions of CSR with organizational commitment. The $p$ and $t$ values reveal that economic CSR, legal CSR, ethical CSR, and philanthropic CSR have significant positive relationship with organizational commitment. The findings show that $15.87 \%$ change in organizational commitment is due to these explanatory variables while remaining is due to unobserved variables. The findings imply that service sector employees consider CSR activities and give weightage to it, and they become more committed towards organization if it is implementing CSR activities.

Discussions and Conclusions. This study analyzes how CSR affects the organizational commitment of employees in the service sector of Kazakhstan. Drawing on a sample of 230 employees from Kazakhstani restaurants, this study finds that employees give weightage to CSR activities while searching for the jobs. This also shows that CSR awareness is increasing rapidly in Kazakhstan, and employees are giving weightage to CSR activities when considering potential jobs. These findings are consistent with Hofman and Newman [65]. The study also finds that employees also consider transparency, fairness, organizational environment, and social relationship. It is also argued that service sector companies respond to the new socio-economic needs in any country. It not only helps them in building the good image among society but also helps in retaining the employees. These findings are consistent with findings of Roudaki and Arslan [39]. 
Table 4 - Results of Regression Analysis

\begin{tabular}{|c|c|c|c|c|c|c|c|c|}
\hline & Model 1 & & & & Model 2 & & & \\
\hline Variables & Beta & $\begin{array}{l}\text { Standard } \\
\text { Error }\end{array}$ & $\mathbf{t}$ & Sig & Beta & $\begin{array}{l}\text { Standard } \\
\text { Error }\end{array}$ & $\mathbf{t}$ & Sig \\
\hline Intercept & 27.625 & 0.4245266 & 65.072 & 0 & 10.909 & 2.65114 & 4.115 & 0 \\
\hline Gender & 0.42045 & 0.6138645 & 0.685 & 0.4941 & 0.549 & 0.57156 & 0.961 & 0.338 \\
\hline Economic CSR & & & & & 0.1639 & 0.06563 & 2.498 & 0.0132 \\
\hline Legal CSR & & & & & 0.1454 & 0.06724 & 2.163 & 0.0316 \\
\hline Ethical CSR & & & & & 0.1551 & 0.07386 & 2.100 & 0.0368 \\
\hline Philanthropic CSR & & & & & 0.1449 & 0.07264 & 1.995 & 0.0472 \\
\hline $\mathrm{R}$ & 0.04531 & & & & 0.3984 & & & \\
\hline $\mathrm{R}^{2}$ & 0.0021 & & & & 0.1587 & & & \\
\hline Adjusted $\mathrm{R}^{2}$ & -0.0023 & & & & 0.1399 & & & \\
\hline Sum of square total & 4941.0 & & & & 4941.0 & & & \\
\hline Df (residual) & 228 & & & & 224 & & & \\
\hline
\end{tabular}

Since employees recognize the importance of CSR; this study examined the effect of perceived CSR on the organizational commitment of employees in the service sector of Kazakhstan. In particular, this study focuses on investigating the link of economic, legal, ethical, and philanthropic CSR with organizational commitment of employees. It is argued that organizational commitment is affected positively due to employees' perception of CSR. Existing studies support this argument and also documented a positive relationship among CSR and organizational commitment [38; 39; 65]. Employees show more loyalty and commitment towards those organizations which implement CSR activities and are transparent. Subsequently, this may increase employees' motivation and performance, and eventually overall firm performance. Therefore, it is pivotal for Kazakhstani firms to adapt CSR activities.

This study supports the notion that firms should endeavor for social and ethical behavior of the organization. The multiple regression analysis showed that philanthropic activities such as "contributing towards the betterment of community" and "helping poor people" and economic CSR activities such as "reducing operating costs" and "establishing long-term strategies" are most significant factors affecting employees' level of organizational commitment. This study highlighted that HR managers should ponder CSR activities in strategy and resource management, communication and organizational practices to boost commitment and finally the firm performance which is similar to the argument of $\mathrm{Fu}$ et al., [66]. Furthermore, transparent and fair policies, and CSR activities help in attracting and retaining qualified and skilled individuals and also increase their motivation and commitment for the organization. The findings of this study showed that service sector firm should not compromise on their CSR activities, especially restaurants and hotels, as this may help in building good image among customers and retaining qualified employees.

This study sheds light on the of CSR initiatives in developing loyal employees. This study also confirms the social identity theory and suggests that employees are social actors who join the organization if it best suits their self-interests, especially in context of CSR. Notwithstanding the significance of CSR awareness, several studies have explored customers' and firms' perceptions, whereas only a few studies have explored employees' CSR perceptions especially in Kazakhstan. This study deepens the knowledge and aftermath of CSR from the employees' perception. It is pivotal to know the employees' perceptions of CSR activities for restaurant management because employees turn CSR statements into actions. According to our best knowledge, 
this is the first study that investigates the impact of CSR on the organizational commitment of service sector employees in Kazakhstan.

Limitations and Directions for Future Research. This study has several limitations and also provides some recommendations for future research. First, the study used the purposive sampling technique and only considered those restaurants of Kazakhstan that have more than 15 employees. The sample size was 230 participants only from the Almaty region, which may not represent the overall service sector or restaurant industry in Kazakhstan. Future scholars may collect data from larger sample and from other sectors. Second, the generalization of findings is limited to restaurants in Kazakhstan; future scholars can explore other cultural contexts and geographical settings, especially Central Asian countries, which will identify new aspects. Third, this study only considered organizational commitment as the dependent variable; future scholars can add more dependent variables like organizational citizenship behavior, employee performance, and satisfaction. In the last, this study only used descriptive statistics, regression, and correlation analysis, future scholars may use other sophisticated statistical techniques like factor analysis and structural equation modeling.

\section{REFERENCES}

1. Mozes M., Josman Z., Yaniv E. Corporate social responsibility organizational identification and motivation // Social Responsibility Journal. - 2011. - № 7. - P. 310-325.

2. Musgrave J. Moving towards responsible events management // Worldwide Hospitality and Tourism Themes. - 2011. - № 3(3). - P. 258-274.

3. Fu H., Ye B. H., Law R. You do well and I do well? The behavioral consequences of corporate social responsibility // International Journal of Hospitality Management. - 2014. - № 40 - P. 62-70.

4. Tsai H., Tsang N. K., Cheng S. K. Hotel employees' perceptions on corporate social responsibility: The case of Hong Kong // International Journal of Hospitality Management. - 2012. - № 31(4) - P. 1143-1154.

5. Marin L., Ruiz S., Rubio A. The role of identity salience in the effects of corporate social responsibility on consumer behavior // Journal of business ethics. - 2009. - № 84(1). - P. 65-78.

6. Kim H. L., Woo E., Uysal M., Kwon N. The effects of corporate social responsibility (CSR) on employee well-being in the hospitality industry // International Journal of Contemporary Hospitality Management. 2018. - P. 1584-1600.

7. Larson B. V., Flaherty K. E., Zablah A. R., Brown T. J., Wiener J. L. Linking cause-related marketing to sales force responses and performance in a direct selling context // Journal of the Academy of Marketing Science. - 2008. - № 36(2). - P. 271-277.

8. Franklin D. E. Just good business: A special report on corporate social responsibility // The Economist. - 2008. - № 386(8563). - 15 p.

9. Moerman L., Van Der Laan S. Social reporting in the tobacco industry: all smoke and mirrors? // Accounting, Auditing \& Accountability Journal. - 2005. - P. 374-389.

10. Leung TC-H., Snell R. S. Strategies for social and environmental disclosure: The case of multinational gambling companies // Journal of business ethics. - 2019. - P. 1-21.

11. Haider M. B., Nishitani K. Views of corporate managers on assurance of sustainability reporting: evidence from Japan // International Journal of Disclosure and Governance. - 2020. - P. 1-19.

12. Bonifácio Neto J., Branco M. Controversial sectors in banks' sustainability reporting // International Journal of Sustainable Development \& World Ecology. - 2019. - № 26(6). - P. 495-505.

13. Bhattacharya C. B., Sen S., Korschun D. Using corporate social responsibility to win the war for talent // MIT Sloan management review. - 2008. - № 49(2). - P. 37-44.

14. Yerniyazova A., Smailova Z. Corporate Social Responsibility Of Business In The Republic Of Kazakhstan // Научный журнал «Доклады НАН РК». - 2019. - № 4. - P. 76-82.

15. Orazalin N. Corporate governance and corporate social responsibility (CSR) disclosure in an emerging economy: evidence from commercial banks of Kazakhstan // Corporate Governance: The International Journal of Business in Society. - 2019. - P. 490-507. 
16. Rodrigo P., Arenas D. Do employees care about CSR programs? A typology of employees according to their attitudes // Journal of Business Ethics. - 2008. - №83(2). - P. 265-283.

17. Jamali D., Karam C. Corporate social responsibility in developing countries as an emerging field of study // International Journal of Management Reviews. - 2018. - №20(1). - P. 32-61.

18. De Roeck K., Farooq O. Corporate social responsibility and ethical leadership: Investigating their interactive effect on employees' socially responsible behaviors // Journal of Business Ethics. - 2018. №151(4). - P. 923-939.

19. Nematullakyzy U. Z., Zhou X., editors. Historical Development of Corporate Social Responsibility Concept in Kazakhstan // International Conference on Geo-Spatial Knowledge and Intelligence. - Springer. 2017. - P. 48-54.

20. Chapple W., Moon J. Corporate social responsibility (CSR) in Asia: A seven-country study of CSR web site reporting // Business \& society. - 2005. - №44(4). - P. 415-441.

21. Donaldson T., Preston L. E. The stakeholder theory of the corporation: Concepts, evidence, and implications // Academy of management Review. - 1995. - №20(1). - P. 65-91.

22. Chapple W., Moon J. CSR agendas for Asia // Corporate Social Responsibility and Environmental Management. - 2007. - №14(4). - P. 183-188.

23. Matten D., Moon J. The dynamics of CSR in a comparative perspective: convergence towards divergent hybrids // Ethical Business Leadership in Troubling Times: Book. - Edward Elgar Publishing. - 2019. - P. $22-40$.

24. Lanis R., Richardson G. Corporate social responsibility and tax aggressiveness: An empirical analysis // Journal of Accounting and Public Policy. - 2012. - №31(1). - P. 86-108.

25. Huseynov F., Klamm B. K. Tax avoidance, tax management and corporate social responsibility // Journal of Corporate Finance. - 2012. - №18(4). - P. 804-827.

26. Cho C. H., Patten D. M. The role of environmental disclosures as tools of legitimacy: A research note // Accounting, organizations and society. - 2007. - №32(7-8). - P. 639-647.

27. Timbate L., Park C. K. CSR performance, financial reporting, and investors' perception on financial reporting // Sustainability. - 2018. - №10(2). - Article 522.

28. El Ghoul S., Guedhami O., Kwok C. C., Mishra D. R. Does corporate social responsibility affect the cost of capital? // Journal of Banking \& Finance. - 2011. - №35(9). - P. 2388-2406.

29. Arslan M., Abeuova D., Alqatan A. Corporate Social Responsibility and Institutional Investors: Evidence from Emerging Markets // Pakistan Journal of Commerce and Social Sciences. - 2021. - №15(1). - P. 31-57.

30. Watson L. Corporate social responsibility, tax avoidance, and earnings performance // The Journal of the American Taxation Association. - 2015. - №37(2). - P. 1-21.

31. Hofstede G. Culture's consequences: International differences in work-related values. - SAGE Publications. $-1984 .-328$ p.

32. Aguilera R. V., Rupp D. E., Williams C. A., Ganapathi J. Putting the S back in corporate social responsibility: A multilevel theory of social change in organizations // Academy of management review. 2007. - №32(3). - P. 836-863.

33. Aguinis H., Glavas A. What we know and don't know about corporate social responsibility: A review and research agenda // Journal of management. - 2012. - №38(4). - P. 932-968.

34. Welford R. Corporate social responsibility in Europe and Asia: Critical elements and best practice // Journal of corporate citizenship. - 2004. - №13. - P. 31-47.

35. Welford R. Corporate social responsibility in Europe, North America and Asia // Journal of Corporate Citizenship. - 2005. - №17(1). - P. 33-52.

36. Forsyth T., editor Enhancing climate technology transfer through greater public-private cooperation: Lessons from Thailand and the Philippines // Natural Resources Forum. - 2005. - №29(2). - P. 165-176.

37. Hills P., Welford R. Ecological modernisation and corporate environmental governance in Hong Kong // International Journal of Innovation and Sustainable Development. - 2005. - №1(1/2). - P. 103-126.

38. Ali A., Nasruddin E., Lin S. K. The relationship between internal corporate social responsibility and organizational commitment within the banking sector in Jordan // International journal of Economics and Management engineering. - 2010. - №4(7). - P. 1842-1861. 
39. Roudaki J., Arslan M. Impact of perceived CSR on organizational commitment: A perspective of service employees // Austin J Bus Adm Manage. - 2017. - №1(3). - Article 1014.

40. Turker D. How corporate social responsibility influences organizational commitment // Journal of Business ethics. - 2009. - 89(2). - P. 189-204.

41. Cullen J. B., Parboteeah K. P., Victor B. The effects of ethical climates on organizational commitment: A two-study analysis // Journal of business ethics. - 2003. - №46(2). - P. 127-141.

42. Collier J., Esteban R. Corporate social responsibility and employee commitment // Business ethics: A European review. - 2007. - №16(1). - P. 19-33.

43. Brammer S., Millington A., Rayton B. The contribution of corporate social responsibility to organizational commitment // The International Journal of Human Resource Management. - 2007. - №18(10). - P. 17011719 .

44. Gong Y., Chang S., Cheung S. Y. High performance work system and collective OCB: A collective social exchange perspective // Human Resource Management Journal. - 2010. - №20(2). - P. 119-137.

45. Farooq O., Payaud M., Merunka D., Valette-Florence P. The impact of corporate social responsibility on organizational commitment: Exploring multiple mediation mechanisms // Journal of Business Ethics. 2014. - №125(4). - P. 563-580.

46. Du S., Bhattacharya C., Sen S. Corporate social responsibility, multi-faceted job-products, and employee outcomes // Journal of Business Ethics. - 2015. - №131(2). - P. 319-335.

47. Mory L., Wirtz B. W., Göttel V. Corporate social responsibility strategies and their impact on employees' commitment // Journal of Strategy and Management. - 2016. - №9(2). - P. 172-201.

48. Mensah H. K., Agyapong A., Nuertey D. The effect of corporate social responsibility on organizational commitment of employees of rural and community banks in Ghana // Cogent Business \& Management. - 2017. - №4(1). - Article 1280895.

49. Thang N. N., Fassin Y. The impact of internal corporate social responsibility on organizational commitment: Evidence from Vietnamese service firms // Journal of Asia-Pacific Business. - 2017. - №18(2). - P. 100-116.

50. Khaskheli A., Jiang Y., Raza S. A., Qureshi M. A., Khan K. A., Salam J. Do CSR activities increase organizational citizenship behavior among employees? Mediating role of affective commitment and job satisfaction // Corporate Social Responsibility and Environmental Management. - 2020. - №27(6). - P. 29412955.

51. Aldag R. J. Multiple Commitments in the Workplace: An Integrative Approach // JSTOR. - 2004. - P. 315-318.

52. Steers R. M. Antecedents and outcomes of organizational commitment // Administrative science quarterly. - 1977. - №2(1). - P. 46-56.

53. Allen N. J, Meyer J. P. The measurement and antecedents of affective, continuance and normative commitment to the organization // Journal of occupational psychology. - 1990. - №63(1). - P. 1-18.

54. Gamble J., Huang Q. Organizational commitment of Chinese employees in foreign-invested firms: Organizational commitment of Chinese employees in foreign-invested firms // The international journal of human resource management. - 2008. - №19(5). - P. 896-915.

55. Meyer J. P., Stanley D. J., Herscovitch L., Topolnytsky L. Affective, continuance, and normative commitment to the organization: A meta-analysis of antecedents, correlates, and consequences // Journal of vocational behavior. - 2002. - №61(1). - P. 20-52.

56. Rego A., Leal S., Cunha M. P., Faria J., Pinho C. How the perceptions of five dimensions of corporate citizenship and their inter-inconsistencies predict affective commitment // Journal of Business Ethics. - 2010. - №94(1). - P. 107-127.

57. Linfei Z., Qingliang G. Corporate social responsibility in china apparel industry // World Academy of Science, Engineering and Technology. - 2009. - №51(2009). - P. 218-222.

58. Murphy V., Abeysekera I. Corporate Social Reporting Practices of Top Indian Software Firms // Australasian Accounting Business \& Finance Journal. - 2008. - №2(1). - P. 36-59.

59. Solinger O. N., Van Olffen W., Roe R. A. Beyond the three-component model of organizational commitment // Journal of applied psychology. - 2008. - №93(1). - P. 70-83. 
60. Shahbudin A. S. M., Nejati M., Amran A. Sustainability-based knowledge management performance evaluation system (SKMPES): linking the higher learning institutes with the bottom billions // African Journal of Business Management. - 2011. - №5(22). - P. 8843-8853.

61. Carroll A. B. A three-dimensional conceptual model of corporate performance // Academy of management review. - 1979. - №4(4). - P. 497-505.

62. Lee Y-K., Lee K. H., Li D-x. The impact of CSR on relationship quality and relationship outcomes: A perspective of service employees // International Journal of Hospitality Management. - 2012. - №31(3). - P. 745-756.

63. Cartwright S., Holmes N. The meaning of work: The challenge of regaining employee engagement and reducing cynicism // Human resource management review. - 2006. - № 16(2). - P. 199-208.

64. Delken M. Organizational cynicism: A study among call centers. - Faculty of Economics and Business Administration, University of Maastricht, Maastricht, 2004. - 62 p.

65. Hofman P. S., Newman A. The impact of perceived corporate social responsibility on organizational commitment and the moderating role of collectivism and masculinity: Evidence from China // The International Journal of Human Resource Management. - 2014. - №25(5). - P. 631-652.

66. Fu F. Q., Bolander W., Jones E. Managing the drivers of organizational commitment and salesperson effort: An application of Meyer and Allen's three-component model // Journal of Marketing Theory and Practice. - 2009. - №17(4). - P. 335-350.

\section{REFERENCES}

1. Mozes, M., Josman, Z. and Yaniv, E. (2011). Corporate social responsibility organizational identification and motivation. Social Responsibility Journal, 7, 310-325.

2. Musgrave, J. (2011). Moving towards responsible events management. Worldwide Hospitality and Tourism Themes, 3(3), 258-274.

3. Fu, H., Ye, B. H. and Law, R. (2014). You do well and I do well? The behavioral consequences of corporate social responsibility. International Journal of Hospitality Management, 40, 62-70.

4. Tsai, H., Tsang, N. K. and Cheng, S. K. (2012). Hotel employees' perceptions on corporate social responsibility: The case of Hong Kong. International Journal of Hospitality Management, 31(4), 1143-1154.

5. Marin, L., Ruiz S. and Rubio, A. (2009). The role of identity salience in the effects of corporate social responsibility on consumer behavior. Journal of business ethics, 84(1), 65-78.

6. Kim, H. L., Woo, E., Uysal, M. and Kwon, N. (2018). The effects of corporate social responsibility (CSR) on employee well-being in the hospitality industry. International Journal of Contemporary Hospitality Management, 1584-1600.

7. Larson, B. V., Flaherty, K. E, Zablah, A. R., Brown, T. J. and Wiener, J. L. (2008). Linking cause-related marketing to sales force responses and performance in a direct selling context. Journal of the Academy of Marketing Science, 36(2), 271-277.

8. Franklin, D. E. (2008). Just good business: A special report on corporate social responsibility. The Economist, 386(8563), 3-24.

9. Moerman, L. and Van Der Laan S. (2005). Social reporting in the tobacco industry: all smoke and mirrors? Accounting, Auditing \& Accountability Journal, 374-389.

10. Leung, TC-H. and Snell, R. S. (2019). Strategies for social and environmental disclosure: The case of multinational gambling companies". Journal of business ethics, 1-21.

11. Haider, M. B. and Nishitani, K. (2020). Views of corporate managers on assurance of sustainability reporting: evidence from Japan. International Journal of Disclosure and Governance, 1-19.

12. Bonifácio Neto, J. and Branco, M. (2019). Controversial sectors in banks' sustainability reporting. International Journal of Sustainable Development \& World Ecology, 26(6), 495-505.

13. Bhattacharya, C. B., Sen, S. and Korschun, D. (2008). Using corporate social responsibility to win the war for talent. MIT Sloan management review, 49(2), 37-44.

14. Yerniyazova, A. and Smailova Z. (2019). Corporate Social Responsibility Of Business In The Republic Of Kazakhstan. Scientific journal "Reports of NAS RK", 4, 76-82. 
15. Orazalin, N. (2019). Corporate governance and corporate social responsibility (CSR) disclosure in an emerging economy: evidence from commercial banks of Kazakhstan. Corporate Governance: The International Journal of Business in Society, 490-507.

16. Rodrigo, P. and Arenas, D. (2008). Do employees care about CSR programs? A typology of employees according to their attitudes. Journal of Business Ethics, 83(2), 265-283.

17. Jamali, D. and Karam, C. (2018). Corporate social responsibility in developing countries as an emerging field of study. International Journal of Management Reviews, 20(1), 32-61.

18. De Roeck, K. and Farooq, O. (2018). Corporate social responsibility and ethical leadership: Investigating their interactive effect on employees' socially responsible behaviors. Journal of Business Ethics, 151(4), 923939.

19. Nematullakyzy, U. Z., Zhou, X. and editors. (2017). Historical Development of Corporate Social Responsibility Concept in Kazakhstan. International Conference on Geo-Spatial Knowledge and Intelligence, Springer, 48-54.

20. Chapple, W. and Moon, J. (2005). Corporate social responsibility (CSR) in Asia: A seven-country study of CSR web site reporting. Business \& society, 44(4), 415-441.

21. Donaldson, T. and Preston, L. E. (1995). The stakeholder theory of the corporation: Concepts, evidence, and implications. Academy of management Review, 20(1), 65-91.

22. Chapple, W. and Moon, J. (2007). CSR agendas for Asia. Corporate Social Responsibility and Environmental Management, 14(4), 183-188.

23. Matten, D. and Moon, J. (2019). The dynamics of CSR in a comparative perspective: convergence towards divergent hybrids: Book Chapter. Ethical Business Leadership in Troubling Times, Edward Elgar Publishing, 22-40.

24. Lanis, R. and Richardson, G. (2012). Corporate social responsibility and tax aggressiveness: An empirical analysis. Journal of Accounting and Public Policy, 31(1), 86-108.

25. Huseynov, F. and Klamm, B. K. (2012). Tax avoidance, tax management and corporate social responsibility. Journal of Corporate Finance, 18(4), 804-827.

26. Cho, C. H. and Patten, D. M. (2007). The role of environmental disclosures as tools of legitimacy: A research note. Accounting, organizations and society, 32(7-8), 639-647.

27. Timbate, L. and Park, C. K. (2018). CSR performance, financial reporting, and investors' perception on financial reporting. Sustainability, 10(2), Article 522.

28. El Ghoul, S., Guedhami, O., Kwok, C. C. and Mishra, D. R. (2011). Does corporate social responsibility affect the cost of capital?. Journal of Banking \& Finance, 35(9), 2388-2406.

29. Arslan, M., Abeuova, D. and Alqatan, A. (2021). Corporate Social Responsibility and Institutional Investors: Evidence from Emerging Markets. Pakistan Journal of Commerce and Social Sciences, 15(1), 3157.

30. Watson, L. (2015). Corporate social responsibility, tax avoidance, and earnings performance. The Journal of the American Taxation Association, 37(2), 1-21.

31. Hofstede, G. (1984). Culture's consequences: International differences in work-related values. SAGE Publications, $328 \mathrm{p}$.

32. Aguilera, R. V., Rupp, D. E., Williams, C. A. and Ganapathi, J. (2007). Putting the S back in corporate social responsibility: A multilevel theory of social change in organizations. Academy of management review, 32(3), 836-863.

33. Aguinis, H. and Glavas, A. (2012). What we know and don't know about corporate social responsibility: A review and research agenda. Journal of management, 38(4), 932-968.

34. Welford, R. (2004). Corporate social responsibility in Europe and Asia: Critical elements and best practice. Journal of corporate citizenship, 13, 31-47.

35. Welford, R. (2005). Corporate social responsibility in Europe, North America and Asia. Journal of Corporate Citizenship, 17(1), 33-52.

36. Forsyth, T. and editor (2005). Enhancing climate technology transfer through greater public-private cooperation: Lessons from Thailand and the Philippines. Natural Resources Forum, 29(2), 165-176. 
37. Hills, P. and Welford, R. (2005). Ecological modernisation and corporate environmental governance in Hong Kong. International Journal of Innovation and Sustainable Development, 1(1/2), 103-126.

38. Ali, A., Nasruddin, E. and Lin, S. K. (2010). The relationship between internal corporate social responsibility and organizational commitment within the banking sector in Jordan. International journal of Economics and Management engineering, 4(7), 1842-1861.

39. Roudaki, J. and Arslan, M. (2017). Impact of perceived CSR on organizational commitment: A perspective of service employees. Austin J Bus Adm Manage, 1(3), Article 1014.

40. Turker, D. (2009). How corporate social responsibility influences organizational commitment. Journal of Business ethics, 89(2), 189-204.

41. Cullen, J. B., Parboteeah, K. P. and Victor, B. (2003). The effects of ethical climates on organizational commitment: A two-study analysis. Journal of business ethics, 46(2), 127-141.

42. Collier, J. and Esteban, R. (2007). Corporate social responsibility and employee commitment. Business ethics: A European review, 16(1), 19-33.

43. Brammer, S., Millington, A. and Rayton, B. (2007). The contribution of corporate social responsibility to organizational commitment. The International Journal of Human Resource Management, 18(10), 17011719 .

44. Gong, Y., Chang, S. and Cheung, S. Y. (2010). High performance work system and collective OCB: A collective social exchange perspective. Human Resource Management Journal, 20(2), 119-137.

45. Farooq, O., Payaud, M., Merunka, D. and Valette-Florence, P. (2014). The impact of corporate social responsibility on organizational commitment: Exploring multiple mediation mechanisms. Journal of Business Ethics, 125(4), 563-580.

46. Du, S., Bhattacharya, C. and Sen, S. (2015). Corporate social responsibility, multi-faceted job-products, and employee outcomes. Journal of Business Ethics, 131(2), 319-335.

47. Mory, L., Wirtz, B. W. and Göttel, V. (2016). Corporate social responsibility strategies and their impact on employees' commitment. Journal of Strategy and Management, 9(2), 172-201.

48. Mensah, H. K., Agyapong, A. and Nuertey, D. (2017). The effect of corporate social responsibility on organizational commitment of employees of rural and community banks in Ghana. Cogent Business \& Management, 4(1), Article 1280895.

49. Thang, N. N. and Fassin, Y. (2017). The impact of internal corporate social responsibility on organizational commitment: Evidence from Vietnamese service firms. Journal of Asia-Pacific Business, 18(2), 100-116.

50. Khaskheli, A., Jiang, Y., Raza, S. A., Qureshi, M. A., Khan, K. A. and Salam, J. (2020). Do CSR activities increase organizational citizenship behavior among employees? Mediating role of affective commitment and job satisfaction. Corporate Social Responsibility and Environmental Management, 27(6), 2941-2955.

51. Aldag, R. J. (2004). Multiple Commitments in the Workplace: An Integrative Approach. JSTOR, 315318.

52. Steers, R. M. (1977). Antecedents and outcomes of organizational commitment. Administrative science quarterly, 2(1), 46-56.

53. Allen, N. J. and Meyer, J. P. (1990). The measurement and antecedents of affective, continuance and normative commitment to the organization. Journal of occupational psychology, 63(1), 1-18.

54. Gamble, J. and Huang, Q. (2008). Organizational commitment of Chinese employees in foreign-invested firms: Organizational commitment of Chinese employees in foreign-invested firms. The international journal of human resource management, 19(5), 896-915.

55. Meyer, J. P., Stanley, D. J., Herscovitch, L. and Topolnytsky, L. (2002). Affective, continuance, and normative commitment to the organization: A meta-analysis of antecedents, correlates, and consequences. Journal of vocational behavior, 61(1), 20-52.

56. Rego, A., Leal, S., Cunha, M. P., Faria, J. and Pinho, C. (2010). How the perceptions of five dimensions of corporate citizenship and their inter-inconsistencies predict affective commitment. Journal of Business Ethics, 94(1), 107-127.

57. Linfei, Z. and Qingliang, G. (2009). Corporate social responsibility in china apparel industry. World Academy of Science, Engineering and Technology, 51(2009), 218-222. 
58. Murphy, V. and Abeysekera, I. (2008). Corporate Social Reporting Practices of Top Indian Software Firms. Australasian Accounting Business \& Finance Journal, 2(1), 36-59.

59. Solinger, O. N., Van Olffen, W. and Roe, R. A. (2008). Beyond the three-component model of organizational commitment. Journal of applied psychology, 93(1), 70-83.

60. Shahbudin, A. S. M., Nejati, M. and Amran, A. (2011). Sustainability-based knowledge management performance evaluation system (SKMPES): linking the higher learning institutes with the bottom billions. African Journal of Business Management, 5(22), 8843-8853.

61. Carroll, A. B. (1979). A three-dimensional conceptual model of corporate performance. Academy of management review, 4(4), 497-505.

62. Lee, Y-K., Lee, K. H. and Li, D-x. (2012). The impact of CSR on relationship quality and relationship outcomes: A perspective of service employees. International Journal of Hospitality Management, 31(3), $745-$ 756.

63. Cartwright, S. and Holmes, N. (2006). The meaning of work: The challenge of regaining employee engagement and reducing cynicism. Human resource management review, 16(2), 199-208.

64. Delken, M. (2004), Organizational cynicism: A study among call centers. 62 p.

65. Hofman, P. S. and Newman, A. (2014). The impact of perceived corporate social responsibility on organizational commitment and the moderating role of collectivism and masculinity: Evidence from China. The International Journal of Human Resource Management, 25(5), 631-652.

66. Fu, F. Q., Bolander, W. and Jones, E. (2009). Managing the drivers of organizational commitment and salesperson effort: An application of Meyer and Allen's three-component model. Journal of Marketing Theory and Practice, 17(4), 335-350.

\title{
КОРПОРАТИВТІ ӘЛЕУМЕТТІК ЖАУАПКЕРШІЛІК ЖӘНЕ ҰЙЫМДАСТЫРУШЫЛЫҚ МІНДЕТТЕМЕ: ҚАЗАҚСТАН ТӘЖІРИБЕСІ
}

\author{
М. Арслан ${ }^{1}$, Д. Әбеуова ${ }^{1 *}$ \\ ${ }^{1}$ КИМЭП Университеті, Алматы, Қазақстан Республикасы
}

\begin{abstract}
АНДАТПА
Зерттеудің мақсаты - корпоративті әлеуметтік жауапкершіліктің (КӘЖ) Қазақстандағы қызмет көрсету қызметкерлерінің ұйымдық міндеттемелеріне қалай әсер ететіндігін талдау болып табылады.

Әдіснамасы: Деректер сауалнама көмегімен жиналды. Қазақстандағы мейрамхана қызметкерлерінен барлығы 230 толық сауалнама алынды. Корпоративті әлеуметтік жауапкершілік пен ұйымдық міндеттеме арасындағы байланысты зерттеу үшін біз Кронбах альфасын, сипаттама статистикасын, корреляциялық талдауын және регрессияны қолдандық.

Зерттеу нәтижесі: Сауалнама нәтижелері көрсеткендей, ұйым КӘЖ қызметіне қатысқан кезде қызметкерлер үлкен ұйымдастырушылық міндеттемелерді көрсетеді. Нәтижелер КӘЖ барлық аспектілері (яғни экономикалық, құқықтық, этикалық және қайырымдылық) арасындағы ұйымдық міндеттемелермен айтарлықтай оң байланысты көрсетеді.

Зерттеудің практикалықжжәе теориялық салдары. Бұл зерттеу адал қызметкерлерді тәрбиелеудегі корпоративті әлеуметтік жауапкершілік бастамаларын қайта анықтауға мүмкіндік береді. Бұл зерттеу сонымен қатар әлеуметтік сәйкестілік теориясын қолдайды және қызметкерлердің жеке мүдделеріне, әсіресе корпоративті әлеуметтік жауапкершілік тұрғысынан сәйкес келетін болса, ұйымға кіретін әлеуметтік субъект болып саналады.

Зерттеудің бірегейлігі / құндылызы: Корпоративті әлеуметтік жауапкершілікті түсінудің маңыздылығына қарамастан, алдыңғы зерттеулер тұтынушылар мен компаниялардың пікірлерін зерттеді. Зерттеулердің кішкене бөлігі ғана қызметкерлердің корпоративті әлеуметтік жауапкершілік туралы түсініктерін талдады. Бұл зерттеу КӘЖ туралы білімді және қызметкерлерге әсерін тереңдетеді.
\end{abstract}


Қызметкерлер мейрамхананы басқару үшін КӘЖ қызметін қалай қабылдайтынын білу қажет, өйткені қызметкерлер КӘЖ мәлімдемелерін іс-әрекетке айналдырады. Біздің білуімізше, бұл КӘЖнің Қазақстандағы қызмет көрсету қызметкерлерінің ұйымдастырушылық міндеттемелеріне әсерін зерттейтін алғашқы зерттеу.

Түйін сөздер: корпоративтік әлеуметтік жауапкершілік, мейрамханалар, ұйымдастырушылық міндеттеме, Қазақстан, регрессия және корреляция.

\title{
КОРПОРАТИВНАЯ СОЦИАЛЬНАЯ ОТВЕТСТВЕННОСТЬ И ОРГАНИЗАЦИОННЫЕ ОБЯЗАТЕЛЬСТВА: ОПЫТ КАЗАХСТАНА
}

\author{
М. Арслан ${ }^{1}$, Д. Абеуова ${ }^{1 *}$ \\ 'Университет КИМЭП, Алматы, Республика Казахстан
}

\begin{abstract}
АННОТАЦИЯ
Цель исследования: Цель этого исследования проанализировать, как корпоративная социальная ответственность (КСО) влияет на организационную приверженность сотрудников сферы услуг в Казахстане.

Методология: Данные были собраны с помощью анкетирования. В общей сложности было получено 230 полных анкет от сотрудников ресторанов в Казахстане. Для исследования связи между корпоративной социальной ответственностью и организационной приверженностью были использованы Альфа Кронбаха, описательная статистика, корреляционный анализ и регрессия.

Результаты исследования показывают, что сотрудники проявляют большую организационную приверженность, если организация участвует в деятельности по КСО. Результаты показывают значительную положительную взаимосвязь всех аспектов КСО (т.е. Экономических, юридических, этических и филантропических) с организационной приверженностью.

Практическое и теоретическое значения исследования. Это исследование проливает свет на пересмотр инициатив в области корпоративной социальной ответственности при воспитании лояльных сотрудников. Это исследование также подтверждает теорию социальной идентичности и предполагает, что сотрудники являются социальными субъектами, которые присоединяются к организации, если это лучше всего соответствует их личным интересам, особенно в контексте корпоративной социальной ответственности.

Оригинальность / иенность исследования: Несмотря на важность осведомленности о корпоративной социальной ответственности, исследования, которые проводились ранее изучали мнения клиентов и компаний. И лишь малая часть исследований анализировали представления сотрудников о корпоративной социальной ответственности. Это исследование углубляет знания и последствия КСО с точки зрения сотрудников. Крайне важно знать, как сотрудники воспринимают деятельность по КСО для управления рестораном, потому что сотрудники превращают заявления КСО в действия. Насколько нам известно, это первое исследование, в котором изучается влияние КСО на организационную приверженность сотрудников сферы услуг в Казахстане.

Ключевые слова: корпоративная социальная ответственность, рестораны, организационная приверженность, Казахстан, регрессия и корреляция.
\end{abstract}

\section{ABOUT AUTHORS}

Muhammad Arslan - Assistant Professor in Acc \& Fin of Bang College of Business (BCB), KIMEP University, Almaty, Republic of Kazakhstan, e-mail: m.arslan@kimep.kz

Dana Abeuova - Assistant Professor in Management of Bang College of Business (BCB), KIMEP University, Almaty, Republic of Kazakhstan, e-mail: d.abeuova@kimep.kz* 


\section{Appendix: A}

Questionnaire

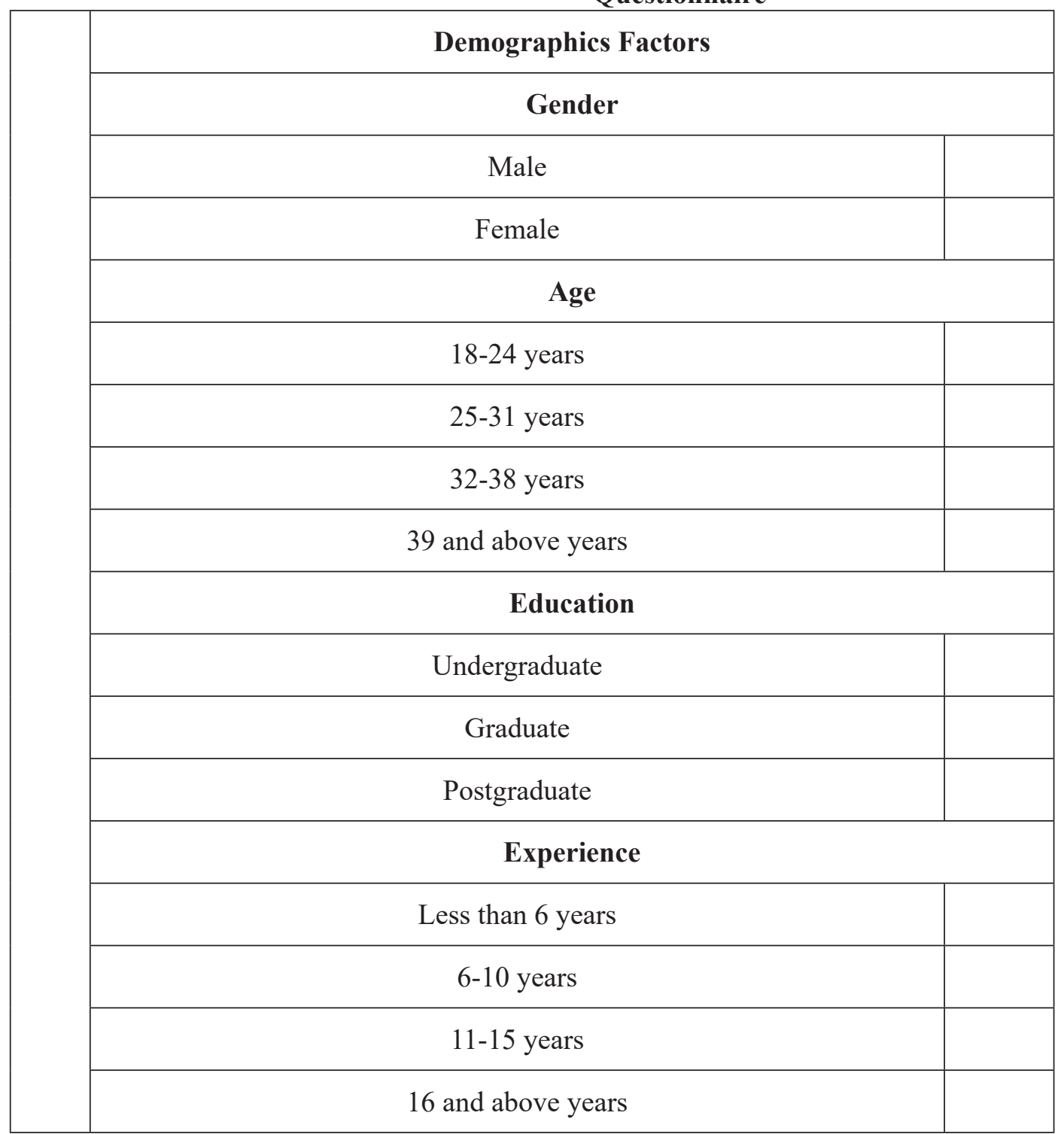

\section{Corporate Social Responsibility (CSR)}

$1=$ Strongly disagree, $2=$ disagree, $3=$ Neutral, $4=$ Agree, $5=$ Strongly agree

\begin{tabular}{|c|c|c|c|c|c|c|}
\hline & Economic CSR & 1 & 2 & 3 & 4 & 5 \\
\hline 1 & $\begin{array}{l}\text { Our business has a procedure in place to respond to every customer } \\
\text { complaint }\end{array}$ & & & & & \\
\hline 2 & We continually improve the quality of our products & & & & & \\
\hline 3 & $\begin{array}{c}\text { We use customer satisfaction as an indicator of our business } \\
\text { performance }\end{array}$ & & & & & \\
\hline
\end{tabular}




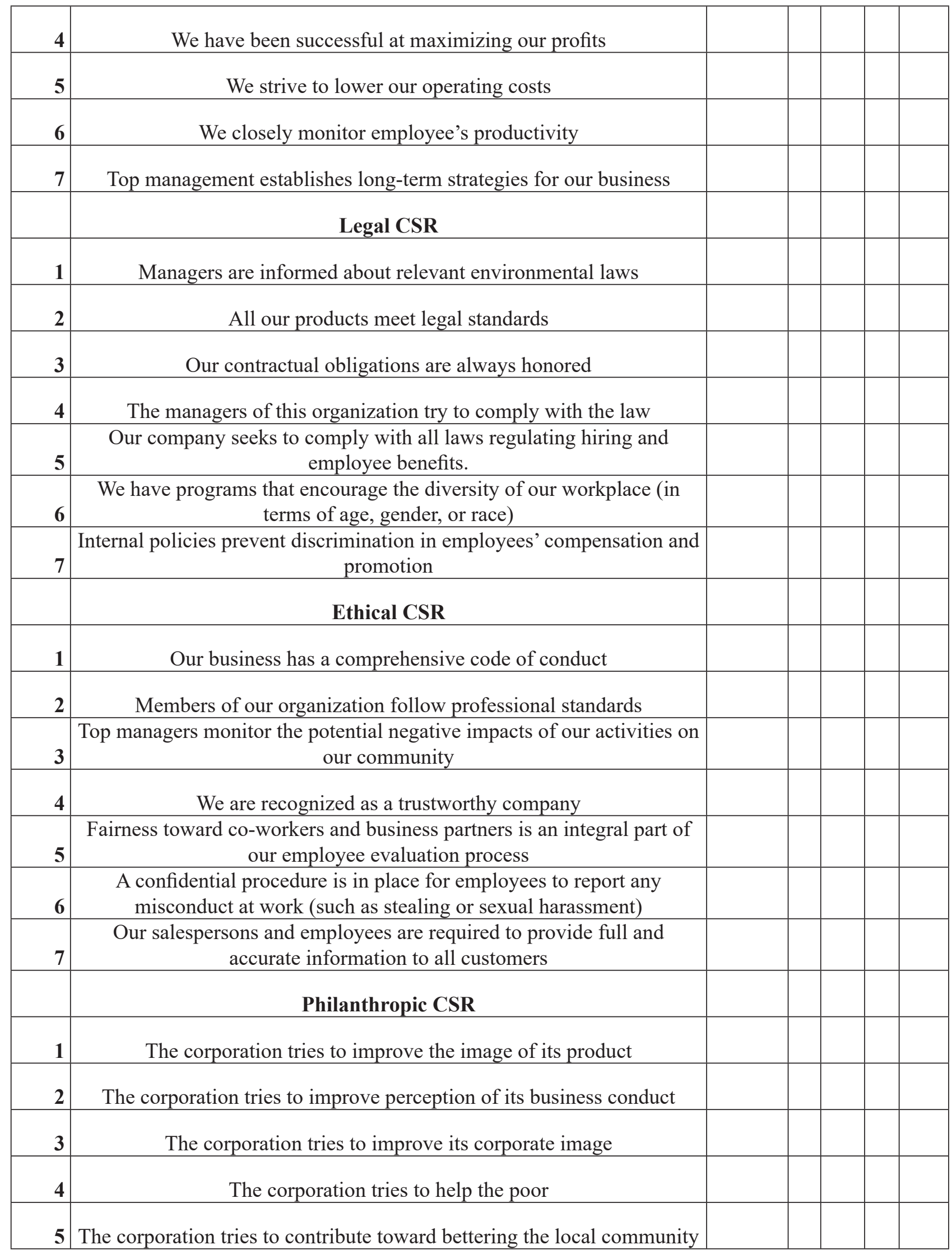




\begin{tabular}{|c|c|c|c|c|c|c|}
\hline 6 & The corporation tries to fulfill its social responsibility & & & & & \\
\hline 7 & The corporation tries to accommodate governmental request & & & & & \\
\hline 8 & The corporation tries to accommodate requests for NGOs & & & & & \\
\hline \multicolumn{7}{|c|}{ Organizational Commitment (OC) } \\
\hline & \multicolumn{6}{|c|}{$1=$ Strongly disagree, $2=$ disagree, $3=$ Neutral, $4=$ Agree, $5=$ Strongly agree } \\
\hline 1 & $\begin{array}{l}\text { I would be very happy to spend the rest of my career with this } \\
\text { organization }\end{array}$ & 1 & 2 & 3 & 4 & 5 \\
\hline 2 & I really feel as if this organization's problems are my own & & & & & \\
\hline 3 & I do not feel like 'part of the family' at my organization & & & & & \\
\hline 4 & I do not feel 'emotionally attached' to this organization & & & & & \\
\hline 5 & I think that people these days move from company to company too often & & & & & \\
\hline 6 & $\begin{array}{c}\text { Jumping from organization to organization does not seem at all unethical } \\
\text { to me }\end{array}$ & & & & & \\
\hline 7 & $\begin{array}{l}\text { It would be very hard for me to leave my organization right now, even if } \\
\text { I wanted to }\end{array}$ & & & & & \\
\hline 8 & $\begin{array}{l}\text { Right now, staying with my organization is a matter of necessity as } \\
\text { much as desire }\end{array}$ & & & & & \\
\hline
\end{tabular}

МРНТИ: 82.15.17

JEL Classification: G30

https://doi.org/10.52821/2789-4401-2021-4-81-99

EARNING MANAGEMENT OF OIL AND GAS AND METAL AND METALLURGY COMPANIES IN RUSSIA

\author{
A. Faizulayev ${ }^{*}$, M. Mashakov ${ }^{1}$, B. Zhussupova ${ }^{1}$,
} ${ }^{1}$ KIMEP University, Almaty, Republic of Kazakhstan

\begin{abstract}
The purpose of research is to identify the relationship between the ownership and earning management on a sample of companies of the oil and gas and metal and metallurgy industries in Russia.

Methodology. Panel data regression analysis was conducted to test research hypothesis. Research covers the data for 2010-2016 periods in regard to two industries - oil and gas production and refinery, ferrous and non-ferrous metallurgy. The theoretical and empirical research suggests that the ownership structure plays an important role for the company performance following the studies of Liu and Lu [1], Ali Shah, Ali Butt and Hasan [2] and Hassan [3].
\end{abstract}

